\title{
ILLICIT CAPITAL FLOW IN CONTEMPORARY ECONOMIES' DEVELOPMENT
}

\author{
Lyudmila Guzikova
}

Igor Lukevich

Peter the Great St. Petersburg Polytechnic University, Saint - Petersburg, Russia

The paper looks into the issues of evaluation and forecast of illicit capital flows. Theoretical statements are analyzed to confirm or reject the reasonability of rigid foreign exchange controls and regulation. A multi-factor linear regression model has been built on the assumption that the volume of illicit capital export depends on the volume of its trans-border flow, which is reflected in the items of the balance of payments of Russia. The model helps to forecast the illicit capital export for the period not yet covered in the public sources of information. Conclusions are made concerning the areas of foreign exchange control which is an important issue for today.

Keywords: illicit capital export, foreign exchange controls, balance of payments, regression model.

\section{Introduction}

The problem of illicit capital flow has a truly global nature. Experts from the organization "Global Financial Integrity" believe that every year the amount of capital which is illicitly exported from developing economies is 1 trillion USD greater than what these countries obtain in the form of foreign direct investments and foreign support taken together. The export of capital from these countries is mostly related to crime, corruption and tax evasion. A number of developing countries throughout many years have been unable to reach the level when they would not need foreign support any more, thus puzzling many economists about their lack of growth despite the large scale of outpouring support (Global Financial Integrity, 2017).
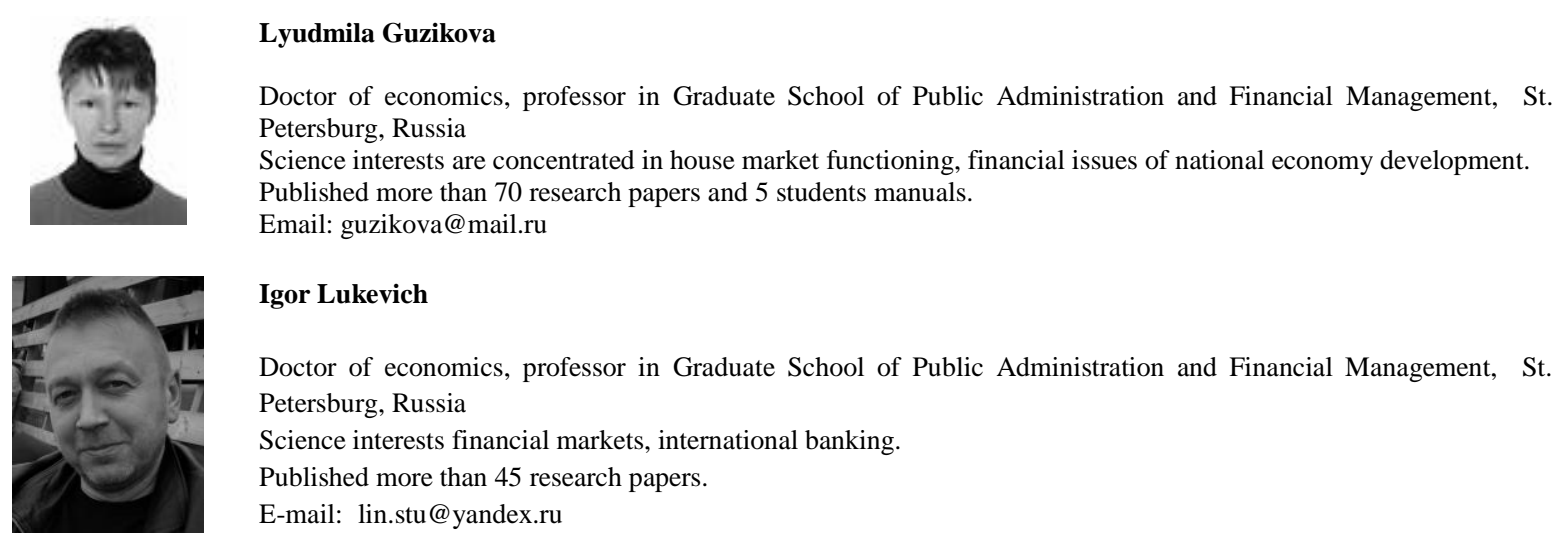


\section{ILLICIT CAPITAL FLOW IN MODERN ECONOMIES’}

B.E. Bernshtam (2013) proves that the main causes for capital outflow from Russia are economic ones and are related to business interests of the owners. Hereof the following key causes are marked out:

- the strive of business units to keep and enlarge their capital and get more earnings than it is possible on the territory of Russian Federation;

- the search for opportunities to evade from paying taxes and/or to legalize the capital obtained in an illegal way.

The first reason is natural for businesses as such. It neither contradicts any national interest, nor brings harm to national economy. However, the export of capital aimed at tax evasion is often called the "flight of capital". According to B.E. Bernshtam (2013), the share of capital exported from Russia for this purpose amounts to 65-75\%. The capital and return on it, in this case, do not go back to the country or, even if they do, only in a form of shortterm investments. The problem of capital export through fraudulent operations and offshore schemes under the conditions of Russian economy integration into the world financial market system has not become less relevant since early 1990s.

In today's conditions, when businesses discuss international flow of financial resources, they speak not about cash flows, as a rule, but about flow of capital, understanding capital as any reserve of benefits capable of bringing income. Under the conditions of trade and financial markets globalization, transborder flows of capital are becoming more and more massive (Nikolova, Kuporov et al., 2015), thus turning into a common feature of this new financial reality (Guzikova, Lukevich, 2016). Legal flow of capital abroad is controllable enough to serve the interests of national economy. Since its methods and scales are known in advance to authorities, it does not create any unexpected effects for the national economy, as opposed to illicit flows of capital.

The purpose of this research study is to justify and construct a model allowing the evaluation and forecast of the the amounts of illicit flows of capital. The objectives of the study are therefore presented as follows:

To define the basic categories such as capital and illegal movement of capital;

To choose the factors affecting the illegal movement of capital, as well as to rank them by their importance;

To develop a regression model of the illicit capital flow, to determine the shape and the form of regression;

To assess the quality of a regression model of the illicit capital flow;

To predict the volume of illicit export of capital from Russia in the short and medium run using the presented above model.

\section{Literature review}

There are numerous interpretations for the notion "capital". It is even harder to define the "international flow of capital" in the context of its forms and tools. Similarly difficult would it be to come to an agreement about how to separate "legal" from "illicit flow of capital". Shadow economy as such includes "informal" economy, i.e. economic activity, allowed by law but hidden so as to evade tax payments; "under-the-table" economy, i.e. criminal economic activity (production and sale of illegal drugs, arms trade, counterfeiting of goods, unlicensed trade, illegal currency operations etc.); "fictitious" economy, i.e. criminal uneconomic activity and earnings from it (extortion, bribery, falsification of figures, thefts, 
robberies, production and distribution of false banknotes, smuggling, false bankruptcies, cheating on customers etc.). The most complicated part of this problem is to separate the common export of capital from its "outflow", "drain" and "flight", as phenomena damaging national economy. The variety of terms used to designate the illicit flows of capital also calls for a more organized conceptual framework, clarification and specification of differences between the notions and more specific determination of the synonyms.

According to M. Dooley, flight of capital is placement of assets outside the control of national authorities. It is calculated as the difference between the total outflow of capital and the amount of external assets (Dooley, 1988).

J. Cuddington (1986) understands the flight of capital as an outflow of short-term capital. It can be calculated as the amount of outflowing short-term capitals and "net errors and omissions".

S. Erbe (1985) sees all types of outflow of private financial assets of any maturity and any type, including direct and portfolio investments as the flight of capital. This vision implies that change in external debt plus inflow of foreign investments is equal to the deficit in the balance of payments plus change in foreign reserves. When the equation turns into an inquation and the left part is bigger than the right one, flight of capital occurs.

D. Lessard and J. Williamson (1987) propose focusing on measuring the total amount of foreign assets purchased by residents and corrected given the derivation of individual elements in the outflow.

Analysts of the international ranking agency "Fitch Ratings", while calculating the drain of capital from Russia, do not consider borrowings of Russian companies from abroad and their foreign direct investments as they believe it is a normal business practice. They think that the drain of capital is increment of foreign assets of the Russian private sector (excluding foreign direct investments abroad) in the sum with "net errors and omissions" (Kornilov, Lobachev, 2008).

The technique suggested by A.S. Bulatov (1999) calculates the export of capital in the following way. The export of capital, according to the narrower definition, is presented as a sum of three summands: non-delivery of export receipts, non-delivery of goods and services in compensation of import advances and net errors and omissions. When evaluating the export of capital according to the broader definition, the following ones are added to the three summands above: capital transfers of emigrants, portfolio investments, loans and credits provided by the bank sector and the sector of non-financial enterprises, balances on current and deposit accounts and foreign currency cash.

I.N. Lukevich (2002) defines the flight of capital as a massive and accelerated export of private capital from the country carried out in commodity and monetary forms, prevailingly in illegal ways, despite profitability of internal investments.

Methodological problems of defining the volumes of capital export have been worked out in the papers by both foreign and Russian scientists. Scientific assessments made to determine the scales of capital export rely on one of these methods:

1) general method, considering the amount of increment in foreign assets (apart from official currency reserves) and the item "errors and omissions" in the balance of payments;

2) determination of the private sector debt - increase in the external debt as a result of money transfer by banks and non-banking institutions;

3) profound analysis of the amount of short-term transfers of capital from the nonbanking private sector and the item "errors and omissions" in the balance of payments; 


\section{ILLICIT CAPITAL FLOW IN MODERN ECONOMIES'}

4) indirect method, evaluating the share of foreign assets not declared for taxation (Kornilov, Lobachev, 2008).

The inflow of foreign direct investments is not always a positive thing for the economy, specifically in the case of Russian Federation. According to (Mirkin, 2013), Russia has created a unique off-shore economy, where the main flow of foreign direct investments both incoming and outgoing - goes in transit through offshores. The share of indirect offshore property is even higher. Transit zone and offshores territories mean that foreign direct investments in Russia are direct only formally. These funds do not serve their economic purposes and do not contribute to transfer of the state-of-the-art equipment, advanced production and management technologies into the country. In Y.M. Mirkin's view, since the 1990s foreign direct investments have been primarily a way to manage risks, to hide property abroad, to reduce taxes, which are very high as for the developing economy of Russia.

Financial instruments are in high demand for speculators, who are attracted by the lack of an adequate system of legal regulation at the derivatives market. Opportunities for speculative operations and risk hedging are the main reasons why there is demand for derivatives both in the countries they are emitted and abroad (Bulatov, 2014). In Russia, legislation and regulatory framework on the market of derivative financial instruments considerably fall behind in comparison to the regulation of other segments of the financial market. The law of the Russian Federation "On commodity exchanges and exchange trade" as of 1992 is virtually the only legal document which regulates transactions with futures and options at exchange markets. The amendments made in this law over many years are minimal. The federal law "On securities market" contains general requirements for stock exchanges trading derivative financial instruments. More essential provisions, including the conceptual framework are presented in the Tax Code of the Russian Federation. However, all these documents must be improved (Polteva, Lukyanova, 2015).

\section{Data and Method}

The paper provides a logical analysis of the causes and effects of the illicit flow of capital and factors included in the balance of payments of the country, based on the statements of the economic theory. The model for illicit flow of capital is constructed and justified on the basis of regression analysis, since it can be used to conclude not only about the cause-effect mechanism, but also to obtain specific data on the type and form of interrelation between the variables in the model (Förster, 1979). The paper uses the methods of pair and multifactor correlation-regression and dispersion analysis.

The analysis made as part of this research is based on the generally accessible statistical information of the Central Bank of the Russian Federation (Central Bank of the Russian Federation, 2017) about the condition of the balance of payments of the country for the years 2004-2015. The information about the amounts of illicit flows of capital from Russia for the years 2004-2013 is given on the website of the above non-profit research and consulting organization the Global Financial Integrity $(G F I)$. This organization investigates the problem of illicit flow of capital. The reliability of the data published by the GFI is ensured by the fact that it has been calculated by the experts of the organizations, who studied statistic data on the balance of payments for 150 developing countries and by the fact that in order to identify dubious deals most attention is paid to the existing gaps in the official 
information on trade, including differences in the accounts of exporting and importing countries (Ifinance, 2013).

\section{Results}

If we suppose that in the trade balance the cumulative amounts of the international corresponding accounts for the beginning of the period and the expected amount of all receipts for a certain period of time should equal to the amounts for the end of the period with the recorded amount of all expenses from these accounts, then the illicit flow of capital can be expressed by the following formula:

$$
F=\left(R_{t}+C r\right)-\left(D r+R_{t+1}\right)+A S(1) \text {, }
$$

where $\mathrm{F}$ - the illicit capital flow for the reviewed period of time, Rt and Rt+1 - the remaining balance in all international corresponding accounts for the beginning and end of the reviewed period respectively, $\mathrm{Cr}$ and $\mathrm{Dr}$ - receipts and expenditures for all corresponding nostro accounts for the reviewed period respectively, AS - amendment caused by legal export of foreign banknotes acquired by the non-banking sector. If $\mathrm{F}>0$, then capital "outflows". If $\mathrm{F}<0$, then capital "inflows". For the purposes of this research study, capital is understood as the financial instruments allowing investing cash reserves, which, in accordance with the standards of international statistic reporting (Central Bank of the Russian Federation. Statistics of the external sector..., 2017) are presented in the balance of payments for the account of operations with capital and financial instruments and imply: direct investments, portfolio investments, derivative financial instruments and other tools.

According to the basic principle of "double entry" in the balance of payments used in accounting, every operation is shown twice by credit of one item and debit of another. The sum total of all credit items in this accounting system must coincide with the sum total of debit ones and their combined balance must be equal to zero. Discrepancies between the sums of credit and debit items are presented in the item "Net errors and omissions". In accordance with the 6th revision of the "Manual of the IMF on the balance of payments and international investment position" (Central Bank of the Russian Federation. Methodological commentary on the balance of payments, 2017), the item "Net errors and omissions" (EO) is the balance of the "financial account" (FA) minus the balance of the "current account and capital account" (CA).

The financial account can be presented as change in the amount of "foreign assets" $(\triangle \mathrm{FA})$ minus change in the amount of "national obligations" $(\Delta \mathrm{NO})$ plus change in the amount of "reserve assets" $(\Delta \mathrm{RA})$. FA and NO include direct, portfolio, other investments and derivative financial instruments:

$$
\mathrm{FA}=(\Delta \mathrm{FA}-\Delta \mathrm{NO})+\Delta \mathrm{RA}
$$

We present the current account as a difference between incoming conditional cash flows from exports (Ex) and conditional outgoing cash flows from imports (Im):

$$
\mathrm{CA}=\mathrm{Ex}-\operatorname{Im}(3)
$$




\section{ILLICIT CAPITAL FLOW IN MODERN ECONOMIES'}

Net errors and omissions are a balancing item and can be presented as:

$$
\mathrm{EO}=\mathrm{FA}-\mathrm{CA}(4)
$$

or

$$
\mathrm{EO}=\Delta \mathrm{FA} \quad \Delta \mathrm{NO}+\Delta \mathrm{RA}-\mathrm{Ex}+\mathrm{Im}(5)
$$

We should note that "reserve assets" (RA) are highly liquid foreign assets which are at the disposal of and controlled by the Central Bank and Government of the country. The data on taken national obligations (NO) are also in control of the state regulatory authorities. Given the above, it can be assumed that reserve assets and national obligations are the items of the balance of payment and the data on them are very reliable and contain no errors or omissions.

The main sources of errors and omissions are operations with foreign assets and import-export operations. Apart from errors preconditioned by the methodology of accounting and having no systematic character, here are presented the results of activity aimed at purposeful distortion of data on the operations made, i.e. illicit flow of capital. If "errors and omissions" have increased considerably, it can be assumed that some foreign assets have not been accounted due to under-declaration of export prices and/or overdeclaration of import prices, which is illicit export of capital. Similarly, if "errors and omissions" have gone down a lot, it means that the reduction of foreign assets is not related to a decrease in exports or growth in imports and, most probably, these assets have been monetized and imported in the country illegally.

In Russia some capital export channels are related to illegal operations, in other words, to operations conducted with relatively slight violations of the RF legislation and/or violations that are hard to prove. Among major types of violations of the Russian legislation committed during illicit capital export, the following ones can be mentioned:

- concealment of transfer, partial or incomplete transfer of export currency receipts to the accounts of Russian banks;

- missed deadlines against the terms established by law for the payment for Russian deliveries by foreign companies (to the extent of non-receipt of funds in residents' accounts) (Artemov, 2013).

The RF balance of payments includes the item "Dubious transactions" (Central Bank of the Russian Federation, 2017, Methodological commentary ...), which includes the signs that an operation is fictitious if it is related to commodity or service trade, purchase/sale of securities, provision of credits and transfer of money in one's own accounts abroad aimed at transborder movement of funds. Until recently, the balance of payments included the following types of such operations: export receipts not obtained in the due time, not delivered goods and services in respect to the money transferred under import contracts, transfers under fictitious operations with securities. Nowadays all these and other methods of illicit capital export are not interpreted and are called dubious operations.

The model for evaluation and forecast of illicit capital flow must allow calculating the amount of requirements and obligations of the RF which are not presented in the account of operations with capital and financial instruments, given the amount of outgoing and incoming cash flows in the RF presented in the current account of the balance of payments. According to the aforementioned, illicit capital flow is understood by the authors as the part of the item "Net errors and omissions" which presents "omissions", i.e. is not explained by 
statistic error of the above item. In other words, the volume of illicit capital flow is seen as a difference in the balance of payments between the account "Current operations" and the account "Operations with capital and financial instruments", which is not presented, given the amounts of outgoing and incoming cash flows from and to the RF included in the item "Net errors and omissions". Illicit capital flow is carried out through operations which are made to get around the rules, limitations and permits of the Central Bank of Russia and, consequently, which end up being not presented in the balance of payments of the RF.

In order to determine the correlation-regression interconnection of the volume of illicit capital flow, it is necessary to investigate the factors affecting its value. In the proposed model, the volume of illicit capital flow is a dependent (interpretable) value Y. The following ones are selected as independent (interpretable) variables: X1 - "Net errors and omissions", X2 - "Export"; X3 - "Import", X4 - "Net import (-) / export (+) of capital by the private sector", X5 - "Dubious transactions", X6 - "Direct investments", X7 - "Portfolio investments"; X8 - "Derivative financial instruments", X9 - "Trade credits and advances", X10 - "Debt tools". Consequently, the volume of illicit capital flow is seen as a function of several interpretable independent variables presented above. Table 1.

The initial data for multiple regression construction are presented in the Appendix of

There are several approaches to solving the problem of selection of the most essential interpretable variables. Let us look into the procedure which implements the idea "from simple to complicated" - subsequent increment of the number of interpretable variables (Kislyak, 2007). In case there are $\mathrm{n}$ variables to participate in the right part, this procedure includes the following steps:

construction of $\mathrm{n}$ pair regressions $\mathrm{Y}$ on $\mathrm{X} 1, \mathrm{Xn}$ and selection of the variable with the highest value of determination coefficient (R-square) R21. At this step, one interpretable variable is found, which can be called the most informative interpretable variable provided that the regression model can include only one of the available set of interpretable variables;

construction of $n^{*}(n-1)$ regressions for various pairs of interpretable variables and selection of the pair which gives the highest value R22 - the most informative pair of variables. This pair will have the tightest statistic connection with the resultant indicator Y.

detection of three most informative interpretable variables through constructing $\mathrm{n} *(\mathrm{n}$ $1)^{*}(\mathrm{n}-2)$ regressions and selecting a triad which ensures the highest value of the determination coefficient $\mathrm{R} 23$.

Based on the analysis of pair regressions, at the first step an interpretable variable "Export" (hereinafter X1) was chosen. It can be characterized as the most informative interpretable variable. The level of determination for the pair regression amounted to 0.6169. The constructed equation of pair linear regression has the following view:

$$
Y_{I C F}=3,932701+0,000214 \times \mathrm{X} 1 \quad(6)
$$

The analyzed regression statistics makes it possible to conclude that the selected independent variable affects the dependent variable. P-statistics proves the importance of the coefficient in case of this variable in the pair linear regression equation for the set level of importance 0.05 . However, distinction of the intercept of the equation from zero is not proved by the corresponding value of P-statistics, so the equation can be rewritten as follows:

$$
Y_{I C F}=0,000214 \times \mathrm{X} 1 \quad(7)
$$

At the second stage we have selected the pair of variables X1 - "Export", X2 "Derivative financial instruments", as the most informative ones in terms of the 


\section{ILLICIT CAPITAL FLOW IN MODERN ECONOMIES’}

determination level. The determination level for this multiple regression is 0.8180 . The regression equation has the following view:

$$
Y_{\text {ICF }}=0,54879+0,000184 \times \mathrm{X} 1+0,018321 \times \mathrm{X} 2
$$

The selected variables affect considerably the interpretable dependent variable. The coefficients in case of both interpretable variables and with the selected dependency level equal to 0,05 are statistically important: $\mathrm{p}$-value of variable $\mathrm{X} 1=0.0048$, for variable $\mathrm{X} 2=0.0272$. The statistical unimportance of the intercept term at this step does not seem to have a considerable defect of the constructed dependency. Given this, the regression equation can be rewritten as follows:

$$
Y_{\text {ICF }}=0,000184 \times \mathrm{X} 1+0,018321 \times \mathrm{X} 2
$$

At the third stage three interpretable variables: X1 - "Export", X2 - "Derivative financial instruments", X3 - "Debt financial instruments" were selected according to the criterion of the maximum informative capacity. The determination level for multiple regression accounted for 0.9663 . The regression statistics of multiple regression are presented in Table 2. The equation of multiple regression of export, derivative financial instruments and debt financial tools by the volume of illicit capital flow, obtained at this stage, has the following view:

$$
Y_{\text {ICF }}=-2,80213+0,000174 \times \mathrm{X} 1+0,012996 \times \mathrm{X} 2+0,001845 \times \mathrm{X} 3 \text { (10) }
$$

The selected independent interpretable variables jointly have a strong influence on the dependent one, since multiple $\mathrm{R} 2=0,983$, i.e. the selected factors by $98.3 \%$ explain the value of the volume of illicit capital flow.

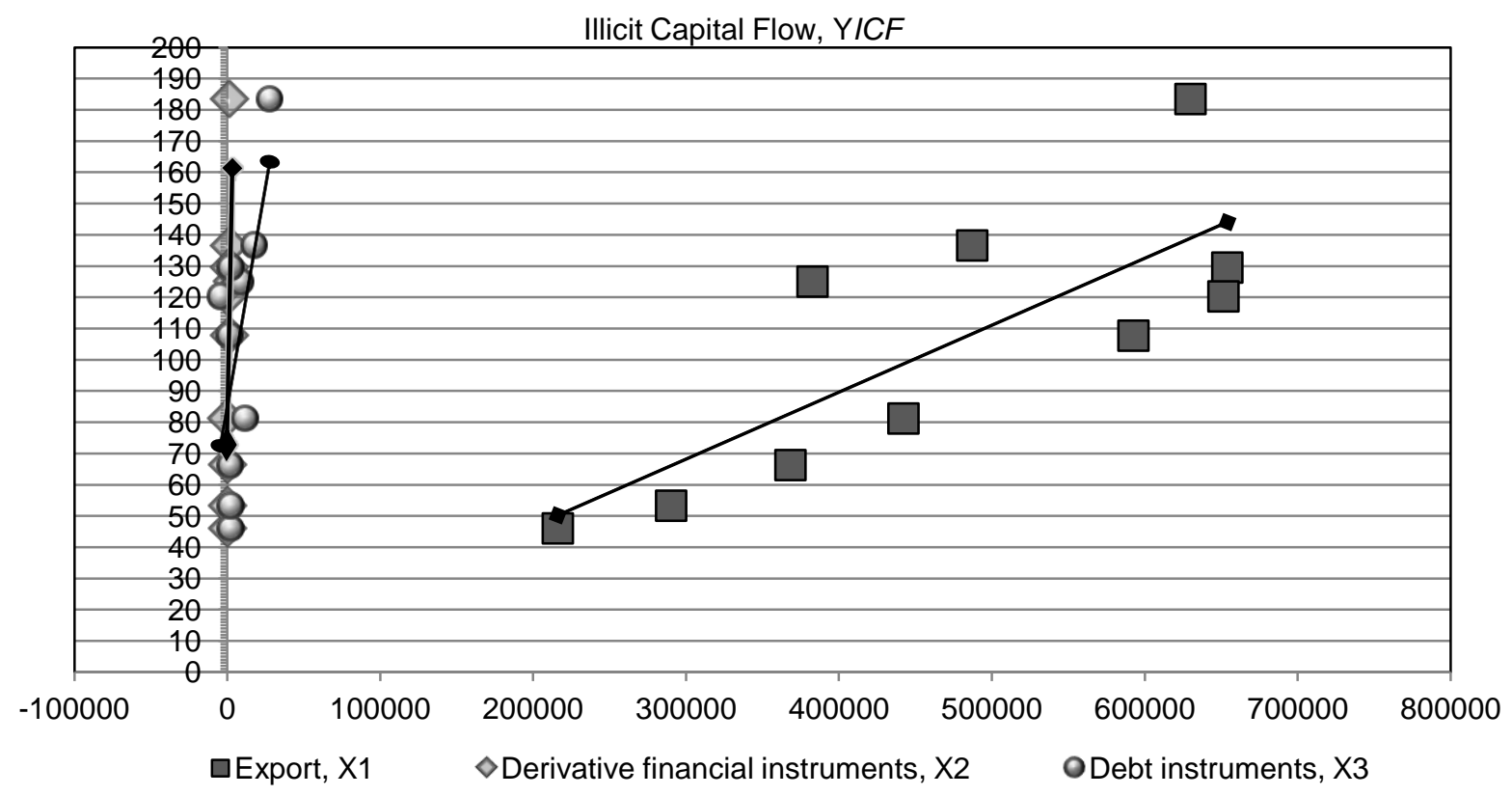

Figure 1. The correlation field of illicit capital flow as an interpreted variable model with interpretable variables

(Constructed by the coauthors)

P-statistics for all three coefficients in case of independent invariables confirm their statistic importance, because all of them are lower than the set level of significance: 
$0.000173<0.05,0.006957<0.05,0.002136<0.05$. P-statistics exceeding the intercept term of the equation and different signs of the confidence limit point to the statistic insignificance of its distinction from zero, so the final view of the equation is the following:

$$
Y_{I C F}=0,000174 \times \mathrm{X} 1+0,012996 \times \mathrm{X} 2+0,001845 \times \mathrm{X} 3(11)
$$

The correlation field constructed by three selected variables is presented in Figure 1.

In order to justify the introduction of all the selected interpretable variables in the model, they were checked for multicollinearity. Based on the recommendations (Dougherty, 2016), it can be assumed that multicollinearity occurs if the coefficient of pair correlation between the factors exceeds the value $r=0.7$. Table 3 presents the results of the calculated coefficients of pair correlation. Since all the coefficients of correlation for independent variables are lower than 0.07 , there is no multicollinearity and no obstacles for including all the selected variables into the model.

Based on the coefficients of correlation between the interpretable factors and the dependent variable, the interpretable factors can be ranged by the degree of significance in the following way:

$\mathrm{X} 1$ - Export (correlation coefficient $\mathrm{r}=0.785$ );

$\mathrm{X} 3$ - Debt financial instruments (correlation coefficient $\mathrm{r}=0.631$ );

$\mathrm{X} 2$ - Derivative financial instruments (correlation coefficient $\mathrm{r}=0.624$ ).

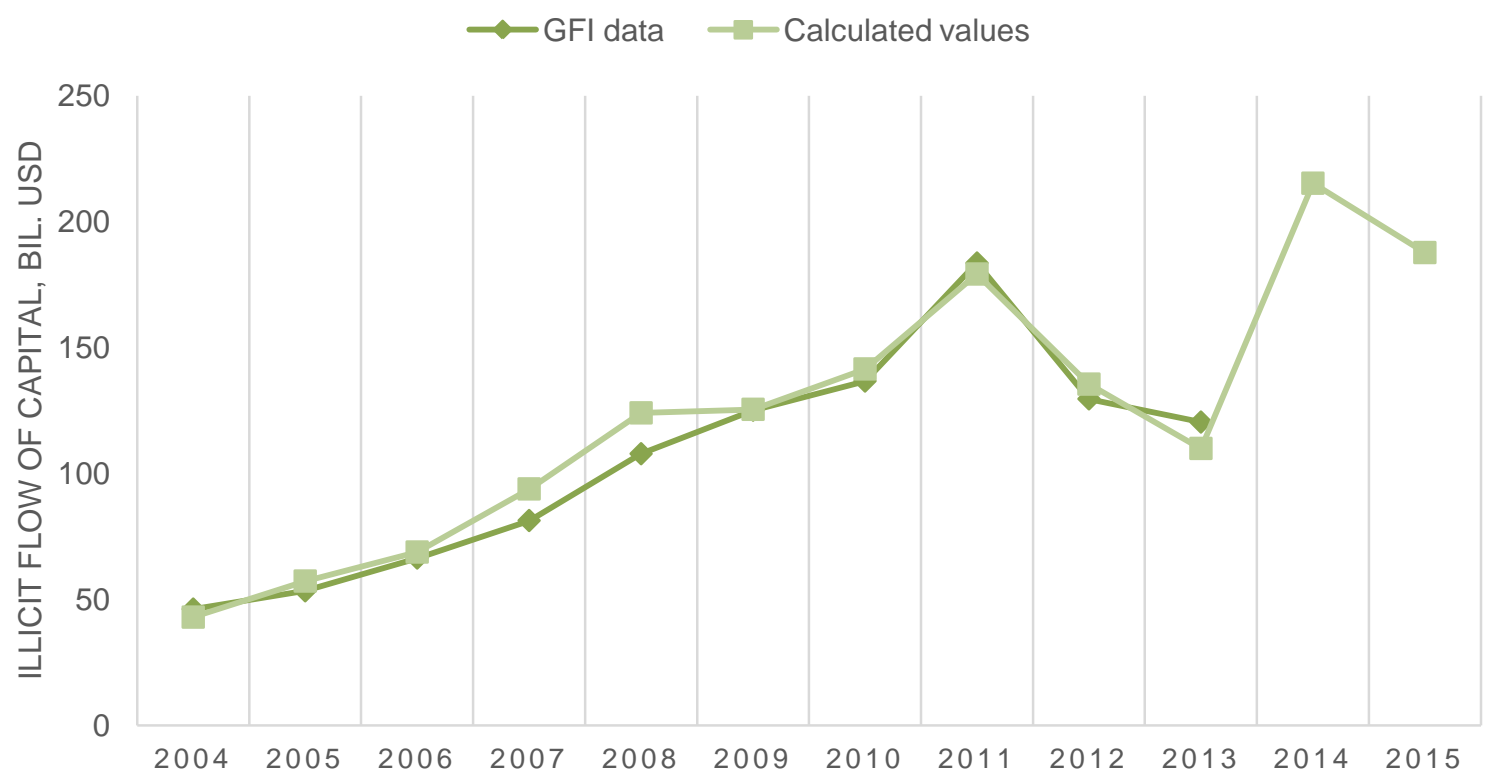

Figure 2. Comparison of the calculated values of illicit capital flow with the GFI data

(Constructed by the coauthors)

Let us use the obtained equation to calculate the values of illicit capital exported in 2014 and 2015. The calculated value of the volume of illicit capital exported in 2014 accounted for 215.186 billion USD, in 2015 - 187.65 billion USD. Lack of data on illicit capital export does not make it possible to verify the precision of the forecast. The calculated values of the amounts of exported capital, obtained by using the constructed model are shown in Table 4. Comparison of the calculated values and official data is given in Figure 2. 


\section{ILLICIT CAPITAL FLOW IN MODERN ECONOMIES'}

Over the period 2004-2013, the average approximation error amounted to $6.77 \%$, which is the evidence of good quality of the constructed model, despite short length of time rows and considerable fluctuations of the initial data.

\section{Conclusions and Directions for Further Investigation}

In this research study we have analyzed the theoretical approaches to investigating the problem of illicit capital export. Even though the first research studies dedicated to this problem date back to several centuries ago, there are still a lot of controversial issues.

Based on the principles of economic theory, causes and effects of illicit capital flow and factors presented in the balance of payments of Russia were logically analyzed. The authors have identified the items of the balance of payments most closely connected with illicit capital flows, which present in the account the operations with capital and financial instruments and are listed from the highest to the lowest in terms of their influence on the volume of illicit capital flow: export, debt financial instruments, derivative financial instruments. The connection between illicit capital export and these items of the balance of payments allows suggesting that they should be the ones to determine the priority directions for counteracting illicit capital export.

In order to construct the model we have used an approach which implies subsequent increment of interpretable derivatives to get regression with acceptable characteristics. It allowed us conclude about the cause-effect mechanism of illicit capital flow and obtain specific results, confirming a linear multifactor interconnection between the variables in the model. In the constructed equation of the multiple linear regression, the volume of illicit capital flow Y represents the function of three variables: "Export", "Debt financial instruments" and "Derivative financial instruments". The model has the determination factor (R2), equal to 96.63 and the significance level of parameter estimators equal to 0.05 . The form of the regression model presupposes that there should be no illicit outflow if the legal outflow operations are absent.

The average approximation error amounted to $6.77 \%$, which is the evidence of good quality of the constructed model, despite the small length of time rows and considerable fluctuations of the initial data. After new data is obtained, this model must be checked and/or improved. In order to do so a technique, similar to the one described in this paper, should be used.

The multiple regression model, developed for evaluation and forecast of illicit capital flow, allows calculating the amount of requirements and obligations of the RF which are not presented in the account of operations with capital and financial instruments, given the amount of outgoing and incoming cash flows in the RF presented in the current account of the balance of payments. The model was used to make a retrospective forecast to assess the volumes of illicit capital export for the period not yet presented in the GFI reports and other public sources.

The results of the regression analysis allow us conclude about the low efficiency of foreign exchange controls in terms of export operations as well as operations with debt obligations and derivative financial instruments. One of the ways to increase this efficiency is to improve legislation and regulatory acts, establishing rules of relevant transactions, controls and liabilities. 


\section{References:}

Artemov, N.M. (2013). Problems and prospects of legal regulation of currency responsibility in the Russian Federation. The issues of economics and law, 1, 7-13.

Bernshtam, B.E. (2013). Specifics of "Capital Flight" from Russia. Bulletin of Tomsk State University. Economics. 3, 113-119.

Bulatov, A.S. (1999). Parameters and Evaluation of the Scales of Capital Outflow from Russia. Money and credit. 12, 68-72.

Bulatov, A.S. (2014). The Russian model of capital export. MGIMO-University. Moscow, 119 p.

Central Bank of the Russian Federation (2017). Methodological commentary to the balance of payment of the Russian Federation. [Electronic resource] URL: http://www.cbr.ru/statistics/credit_statistics/meth-kom-bop.pdf (date of visit 08.02.2017)

Central Bank of the Russian Federation, (2017). URL: www.cbr.ru (date of visit 08.02.2017)

Central Bank of the Russian Federation. (2017). Statistics of the external sector. Balance of payments (RPB6), URL: www.cbr.ru

Cuddington, J.T. (1986). Capital Flight: Issues and Explanations. Princeton Studies in International Finance 58, 44. Princeton University, Princeton.

Dooley, M. (1988). Capital flight: A response to differences in financial risks. IMF Staff papers 35, $422-436$.

Dougherty, C. (2016). Introduction to Econometrics, 5the ed. Oxford University Press, 5, 608.

Erbe, S. (1985). The Flight of capital from Developing Countries. Intereconomics, 20, 268-275.

Förster, E., Rönz, B. (1979). Methoden der korrelations- undregressionsanalyse. Verlag Die Wirtschaft, Berlin, 324.

Global Financial Integrity. (2017). URL: www.gfintegrity.org (date of visit 08.02.2017)

Guzikova, L.A., Lukevich, I.N. (2016). New financial reality in the light of monetary theory. Konzeptuelle grundsatze des wirtschaftswwachstums bei der globalisierung. Kollektive monographie. Herausgegeben vom doktor der wirtschaftssenschaften. Professor W. Jatsenko.Verlag SWG index GmbH Nurnberg, Deutschland, 146-157.

IFinance, 2013, Illicit outflow of capital in the years 2002-2011. URL: http://globalfinances.ru/global-financial-integrity-nezakonnyiy-ottok-kapitala-v-2002-2011-godah/ (date of visit 10.02.2017)

Kislyak, N.V. (2007). Econometrics. State educational institution of higher professional education "Ural State University named after A.M. Gorky". Ekaterinburg, 154

Kornilov, M.Y., Lobachev, S.V. (2008). How to evaluate the volume of capital flying from Russia. Economic bulletin of Rostov State University, 1, 78-85.

Lessard, D.R., Williamson, J. (1987). Capital Flight and Third World Debt, Institute for International Economics, Washington, DC, 97-100.

Lukevich, I.N. (2002). Evaluation of illicit capital flow in Russia. Financial world. Moscow. 145-152.

Mirkin. Y.M. (2013). Railway station for investments. Direct investments, 10, 14-16.

Nikolova, L.V., Kuporov, J.J., Rodionov, D.G. (2015). Risk management of innovation projects in the context of globalization. International Journal of Economics and Financial Issues, 5, 73-79.

Polteva, T.V., Lukyanova E.S. (2015). Practical application of derivatives as risk hedging tools. Bulletin of Nizhny Novgorod State University of Engineering and Economics, 1, 69-74.

Paper submitted

Paper accepted for publishing

Paper published online
11 October 2017

19 December 2017

01 February 2018 